\title{
PENINGKATAN AKTIVITAS DAN HASIL BELAJAR IPA DENGAN MODEL KOOPERATIF TIPE THINK PAIR SHARE DI KELAS VI SDN 15 PAKASAI KECAMATAN PARIAMAN TIMUR
}

\author{
Agustrinaldi \\ Surel: naldi_des@yahoo.com
}

\begin{abstract}
The background of the problem in this research was the students seemed to be less active in the learning process as the class was dominated by the teacher. So that it caused very minimal student activity and student learning outcomes is low. This research was aimed to improve learning outcomes IPA with cooperative models type think of pair share in class VI SDN 15 Pakasai. The results showed that in the first cycle, the overall activity of students scored an average of 51,3, in the second cycle increased to 81,6. From an average cognitive aspects of student learning result in the first cycle got 70 score on the second cycle increased to 88. Affective aspects in the first cycle get an average value of 50,5 and in the second cycle value of 80,2. Psychomotor aspects of the first cycle get an average value of 58,6 in the second cycle increased to 92,3. Based on these result, it was concluded that the use of cooperative model tps type can increase the activity and learning outcomes of sixth grade students of SDN 15 Pakasai Pariman city.
\end{abstract}

Keywords: Cooperative Type Think-Pair-Share Results Learning, Student Activities

\section{PENDAHULUAN}

Ilmu Pengetahuan Alam (IPA) merupakan salah satu bidang studi yang diajarkan di Sekolah Dasar (SD). Dengan pembelajaran IPA siswa dapat mengenal lingkungan sekitar beserta segala isinya, melalui berbagai aktivitas yang dilakukan oleh siswa dalam kegaiatan pembelajaran. Proses pembelajaran IPA menekankan pada pemberian pengalaman langsung dan kegiatan praktis, untuk mengembangkan berbagai kompetensi agar siswa dapat memahami alam sekitar secara ilmiah. Hal ini dijelaskan dalam Depdiknas (2006:484) bahwa "Pembelajaran IPA merupakan cara mencari tahu tentang alam sekitar secara sistematis, sehingga IPA bukan hanya sekedar penguasaan keterampilan, pengetahuan yang berupa fakta-fakta, konsep-konsep atau prinsip-prinsip saja tetapi juga merupakan proses penemuan melalui percobaan-percobaan dalam proses pembelajaran".

Berdasarkan penjelasan tersebut dapat diperoleh pengetahuan bahwa pembelajaran IPA bukan hanya didapatkan dari kegiatan menerima materi pembelajaran yang sudah ada. Seharusnya dalam pembelajaran IPA siswa harus aktif dengan berbagai aktivitas yang dilakukannya dalam pembelajaran. Untuk mengaktifkan siswa dalam belajar dapat dilakukan dengan melakukan percobaan, 
mengamati, menganalisis dan diskusi kelompok untuk menemukan kebenaran suatu fakta atau konsepkonsep dari materi pembelajaran yang dipelajarinya.

Kebanyakan pembelajaran IPA yang terjadi di SD tidak sesuai dengan hakekat pembelajaran IPA yang sesungguhnya. Berdasarkan hasil temuan dan observasi peneliti, ditemukan bahwa proses pembelajaran IPA cenderung berlangsung dengan lebih didominasi oleh guru dan siswa tidak dilibatkan secara aktif dalam belajar. Siswa hanya mendengarkan ceramah dari guru dan ditugaskan untuk mencatat ringkasan materi pelajaran yang didiktekan oleh guru. Setelah itu siswa ditugaskan untuk menjawab pertanyaan yang ada pada buku paket. Keadaan seperti ini menjadikan pembelajaran kurang bermakna bagi siswa dan pengalaman belajar tidak terbentuk dalam diri siswa, dan tentu saja siswa akan cepat lupa dengan materi pelajaran yang telah dipelajarinya. Hal ini mengakibatkan sebahagian besar nilai ulangan harian dan nilai semester siswa rendah dalam pembelajaran IPA. Artinya terdapat permasalahan yang telah dilakukan dalam proses pembelajaran IPA terutama kesalahan dari aspek guru.

Kesalahan yang dilakukan oleh guru adalah proses pentransferan ilmu dari guru kepada siswa yang tidak tepat. Sehingga tidak terjadi interaksi pembelajaran yang baik antara guru dengan siswa dan antara siswa dengan siswa. Hal ini terjadi karena guru lebih mendominasi jalannya proses pembelajaran sehingga siswa bersifat pasif dalam dalam belajar. Guru juga kurang mampu untuk mengeksplorasi siswa, padahal siswa memiliki skemata yang harus digali dan dikembangkan guna membuka wawasan siswa dalam belajar. Skema siswa dapat dikembangkan dengan melakukan tanya jawab dan menggunakan berbagai media yang tepat dan sesuai dengan materi pelajaran. Padahal jika skemata ini dapat dieksplor dengan baik, maka siswa akan lebih cepat menyerap materi pelajaran yang akan diterimanya.

Guru juga kurang mampu mengelaborasi siswa dalam pembelajaran, semua kegiatan pembelajaran dikendalikan oleh guru. Adapun kegiatan elaborasi yang dapat dilakukan oleh guru terhadap siswa dalam pembelajaran adalah seperti berdiskusi, bekerja dalam kelompok untuk mengamati, mengumpulkan data, menemukan suatu konsep, dan meyimpulkan materi yang telah didapatkanya secara berkelompok. Guru juga kurang mampu mengkonfirmasikan pembelajaan. Seolah-olah setelah jam pembelajaran selesai, guru berasumsi bahwa materi pelajaran yang telah disajikannya telah tercapai. Padahal masih banyak hal-hal yang harus diperhatikannya diakhir pembelajaran, seperti memberi penegasan dan penguatan kembali dari materi yang telah 
disampaikannya pada siswa, serta yang terpenting adalah bagaimana guru merumuskan kesimpulan dari materi pelajaran yan telah diterima siswa.

Sudah seharusnya seorang guru mampu merancang dan melaksanakan suatu pembelajaran IPA dengan melibatkan siswa dengan berbagai aktivitas dalam pembelajaran. Sehubungan dengan hal ini Hamalik (2008:171) menjelaskan bahwa "pembelajaran yang efektif adalah pembelajaran yang menyediakan kesempatan pembelajaran sendiri atau melakukan aktivitas sendiri bagi siswa sedangkan guru hanya bertugas sebagai fasilitator atau pemandu dalam pembelajaran". Guru sebaiknya bisa menciptakan suatu proses pembelajaran yang kondusif, menyenangkan, dan dapat mengaktifkan siswa dalam belajar. Siswa harus diaktifkan dalam belajaran sehingga tidak hanya menerima materi yang disampaikan oleh guru secara instan, siswa harus mampu menemukan sendiri konsep dari materi yang dipelajarinya secara mandiri ataupun secara kooperatif. Hal ini dapat dilakukan dengan menggunakan model pembelajaran yang inovatif dalam mengajar. Model pembelajaran yang dapat digunakan oleh guru untuk meningkatkan aktivitas dan hasil belajar IPA adalah model kooperatif tipe Think-PairShare (TPS).

Menurut Trianto (2011:81)

model koopertif tipe TPS "merupakan jenis pembelajaran koopertif yang dirancang untuk mempengaruhi pola interaksi siswa. TPS memberikan siswa lebih banyak waktu berpikir, untuk merespon dan saling membantu dalam belajar". Dengan menggunakan model koopertif tipe TPS ini, banyak melibatkan siswa untuk menemukan konsep materi pelajaran melalui penemuan yang dilakukannya secara kolaboratif. Siswa juga mampu mengamati, mencerna, mengidentifikasi, menjelaskan dan membuat kesimpulan dalam usaha memahami suatu konsep. Siswa juga dapat memperoleh pengalaman langsung untuk mengembangkan kompetensinya agar mampu menjelajahi dan memahami alam sekitar secara ilmiah. Sehingga dengan model kooperatif tipe TPS ini dapat meningkatkan aktivitas dan hasil pembelajaran IPA di kelas VI SD.

Berdasarkan identifikasi masalah, penelitian ini difokuskan pada usaha peningkatan aktivitas dan hasil belajar siswa dalam pembelajaran IPA dengan menggunakan model kooperatif tipe TPS di Kelas VI SD. Adapun rumusan masalah dalam penelitian ini adalah: Bagaimanakah peningkatan aktivitas dan hasil belajar siswa dalam pembelajaran IPA dengan menggunakan model Kooperatif tipe TPS di Kelas VI SD?. Berdasarkan rumusan masalah tersebut, maka penelitian ini bertujuan untuk mendeskripsikan peningkatan 
aktivitas dan hasil belajar siswa dalam pembelajaran IPA dengan menggunakan model Kooperatif Tipe Think-Pair-Share (TPS) di Kelas VI SD

Penelitian ini diharapkan dapat memberikan manfaat, baik yang bersifat teoritis maupun yang bersifat praktis. Secara teoritis dapat bermanfaat sebagai sebagai salah satu masukan atau sumbangan pemikiran terhadap khasanah keilmuan, dalam rangka memperbaiki dan meningkatkan mutu pembelajaran terutama pada pembelaajran IPA dengan penggunaan model kooperatif tipe TPS di SD. Secara praktis bagi guru dapat dijadikan sebagai pedoman dan panduan dalam usaha untuk meningkatkan aktivitas dan hasil belajar siswa dalam pembelajaran IPA di SD. Bagi siswa, dapat meningkatkan aktivitas dan hasil belajarnya dalam pembelajaran IPA.

\section{METODE PENELITIAN}

Penelitian ini menggunakan pendekatan kualitatif. Menurut Dwiyanto (2008:2) "penelitian kualitatif adalah cara pengumpalan data yang lazim dilakukan melalui studi pustaka dan studi lapangan. Peneliti mengumpulkan data dengan bersentuhan langsung dengan situsai lapangan, misalnya mengamati, wawancara, diskusi kelompok, atau terlibat langsung dalam penelitian". Jenis Penelitian ini adalah Penelitian Tindakan Kelas (PTK). Dalam penelitian tindakan kelas diadakan perlakuan tertentu yang didasarkan pada masalah-masalah aktual yang ditemukan di lapangan. Menurut Arikunto (2007:3) "Penelitian tindakan kelas merupakan suatu pencermatan terhadap kegiatan belajar berupa sebuah tindakan, yang sengaja dimunculkan dan terjadi dalam sebuah kelas secara bersama. Tindakan tersebut diberikan oleh guru dan atau dengan arahan dari guru yahng dilakukan oleh siswa"

Penelitian ini dilaksanakan di kelas VI SDN 15 Pakasai Kecamatan Pariaman Timur Kota Pariaman. Sebagai subjek dalam Penelitian ini adalah siswa kelas VI SDN 15 Pakasai kota Pariaman, yang berjumlah 6 orang yang terdiri dari 4 orang siswa lakai-laki dan 2 orang siswa perempuan. Siswa-siswa ini terdaftar pada semester I tahun ajaran 2012-2013. Penelitian dilakukan selama 2 siklus, dengan 2 kali pertemuan pembelajaran untuk setiap siklusnya. Alur penelitian ini terbagi atas empat tahap yaitu: (1) Perencanaan, (2) Pelaksanaan, (3) Pengamatan dan (4) Refleksi.

\section{HASIL DAN PEMBAHASAN Penelitian Siklus I}

Pembahasan hasil penelitian siklus I meliputi: (a) Pelaksanaan Pembelajaran IPA dengan menggunakan model kooperatif tipe TPS, (b) Aktivitas belajar siswa dengan menggunakan model kooperatif tipe TPS dan (c) Hasil belajar siswa dengan menggunakan model kooperatif tipe TPS. Dalam 
pelaksanaan pembelajaran, terlebih dahulu disusun rencana pelaksanaan pembelajaran. Perencanaan pembelajaran ini menjadi gambaran dari kegiatan yang akan diterapkan atau dilaksanakan selama proses pembelajaran. Kemudian baru dilanjutkan dengan menyusun langkah-langkah kegiatan pembelajaran. Untuk itu, langkah pembelajaran yang baik harus mencerminkan berbagai aspek sebagai sebuah sistem. Kegiatan pembelajaran ditulis secara berurutan dari awal sampai kegiatan pembelajaran selesai. Dari penjelasan tersebut kegiatan pembelajaran terdiri atas kegiatan awal, kegiatan inti dan kegiatan akhir.

Pada saat kegiatan awal, pembelajaran difokuskan untuk membuka skemata siswa untuk belajar. Karena dengan membuka skemata yang ada pada siswa, maka siswa akan lebih mudah menyerap dan memahami maeri pelajaran yang akan dipelajarinya. Untuk membuka skemata siswa dalam belajar, guru mengadakan tanya jawab dengan siswa tentang hewan-hewan yang ada di lingkungan tempat tinggalnya. Kemudian guru juga menampilkan alat peraga audio visual sehingga lebih jelas untuk dilihat dan didengar oleh siswa. Skemata siswa juga dikembangkan dengan menampilkan hewan yang akan diidentifikasi ciri khususnya dalam bentuk atau wujud yang asli. Hal ini tentu saja akan lebih menjadikan pembelajaran lebih nyata (kontekstual) bagi siswa dalam belajar. Menurut Sanjaya (2008:255) "pembelajaran yang menekankan kepada proses keterlibatan siswa secara penuh untuk dapat menemukan materi yang dipelajari dengan menghubungkannya dengan situasi kehidupan nyata". Berdasarkan landasan teori tersebut dapat diperoleh penjelasan bahwa pembelajaran akan dapat berlangsung dengan baik, apabila pembelajaran lebih bersifat nyata atau dekat dengan kehidupan siswa. untuk itu peneliti membawa bentuk hewan asli ke dalam kelas untuk membuka skemata siswa dalam kegiatan pembelajaran.

Tahap kegiatan inti pembelajaran siswa diarahkan untuk melakukan diskusi kelompok dalam belajar. Karena dengan belajar kooperatif (berkelompok), siswa akan lebih termotivasi dalam belajar serta mampu menyelesaikan tugas belajarnya dengan lebih mudah dan cepat. Keadaan ini di dukung dengan adanya kerjasama yang saling aktif antara siswa. Hal ini sesuai dengan pendapat Asma (2006:26) yang menjelaskan bahwa "pembelajaran kooperatif daapt menyebabkan unsurunsur psikologis siswa siswa menjadi teransang dan menjadi lebih aktif. Karena adanya rasa kebersamaan dalam kelompok, sehingga mereka dengan mudah dapat berkomunikasi dengan bahasa yang lebih sederhana". Jadi dengan pembelajaran dengan model kooperatif siswa dapat lebih mudah dalam menemukan konsep dalam pembelajaran. 
Peneliti menggunakan model pembelajaran kooperatif tipe TPS dalam kegiatan pembelajaran. Siswa dibagi atas kelompok belajar yang beranggotakan 2 orang siswa dalam setiap kelompok. Hal ini sesuai dengan pendapat Suyatno (2009:54) yang menjelaskan bahwa "guru memberikan persoalan kepada siwa dan siswa bekerja kelompok dengan cara berpasangan sebangku-sebangku dalam belajar". Pemilihan model kooperatif tipe TPS ini didasarkan oleh jumlah siswa kelas VI SDN 15 pakasai yang berjumlah 6 orang. Sehingga pembelajaran kooperatif TPS ini peneliti anggap tepat, kemudian selama ini siswa juga jarang belajar secara kooperatif apalagi belajar kooperatif TPS belum pernaah selama ini. Dalam kegiatan pembelajaran siswa mendiskusikan tentang ciri khusus yang dimiliki oleh bebek ayam pada pertemuan pertama dan mendiskusikan ciri khusus yang dimiliki oelh cicak dan lipas pada pertemuan kedua.

Kegiatan diskusi atau pair pada siklus I ini kurang berjalan dengan kondusif. Karena tindakan siswa dalam diskusi yang kurang tenang sehingga menimbulkan suasana yang agak ribut dalam kelas. Siswa seperti bermain-main dengan hewan yanga ada pada kelompok masing-masing. Siswa belum begitu mampu untuk mengidentifikasi ciri khusus dari hewan yang sedang didiskusikanya. Sehingga pembelajaran berlangsung kurang efektif dan efisien. Guru juga kurang mampu membantu kendala siswa dalam berdiskusi, guru terlihat hanya fokus pada satu kelompok saja. Hal ini menyebabkan pengalaman belajar tidak terbentuk dalam diri siswa, karena pembelajaran berlangsung kurang bermakna.

Pada saat kegiatan share berlangsung, siswa masih kurang mampu untuk saling share dengan temannya dengan baik. Siswa belum mampu menjelaskan konsep dari materi pelajaran yang telah mereka diskusikan. Siswa yang bertindak sebagai pendengar juga belum mau mendengar dengan penuh perhatian. Hal ini disebabkan oleh sikap siswa yang masih acuh terhadap teman share nya. Kegiatan share ini juga kurang dipandu oleh guru dengan baik. Seharusnya guru lebih menjelaskan cara melakukan share dengan lebih jelas kepada siswa. Agar siswa lebih terarah dan mengerti dalam share.

Dalam penelitian ini peneliti merancang suatu pembelajaran yang mengaktifkan siswa dalam belajar. Siswa dilibatkan dengan berbagai kegiatan. Sehingga siswa tidak hanya pasif mendengar ceramah dari gurunya. Pembelajaran seperti ini akan menjadi lebih bermakna bagi siswa dan materi pelajaran tidak akan cepat dilupakan oleh siswa. Hal ini juga dijelaskan oleh Sardiman (2007:97) bahwa "dalam kegiatan belajar siswa harus aktif berbuat, dengan kata lain dalam belajar sangat diperlukan aktivitas karena tanpa aktivitas proses belajar tidak mungkin 
berlangsung dengan baik". Berdasarkan hal ini peneliti berusaha untuk mengaktifkan siswa dengan berbagai aktivitas dalam pembelajaran IPA dengan menggunakan model kooperatif tipe TPS dalam penelitian ini.

Ada lima aktivitas yang peneliti amati dalam penelitian ini, kelima aktivitas itu harus mampu dilakukan oleh siswa secara optimal. Peneliti berusaha agar tidak ada lagi siswa pasif dalam pembelajaran. Aktivitas yang peneliti amati dalam penelitian ini adalah: (1) Visual activities, (2) Listening activities, (3) Oral activities, (4) Writing activities, dan (5) Emotional activities. Kelima aktivitas yang akan diamati diukur dengan terlebih dahulu menetapkan deskriptor-deskriptor yang harus dilakukan oleh siswa, dimana untuk setiap aktivitas dibuat empat deskriptor.

Visual activities siswa pada pada siklus I belum dapat dilakukan oleh siswa sepenuhnya. Hal ini dapat dilihat dari sikap siswa yang kebanyakan belum serius menyimak seluruh kegiatan pembelajaran secacara penuh. Pada saat penyampaian tujuan pembelajaran siswa kurang memperhatikan guru, mereka tidak fokus dan sepertinya acuh terhadap guru yang ada di depan kelas. Pada saat diskusi kelompok untuk mengidentifikasi cirri khusus makhluk hidup, siswa kelihatan masih setengah hati untuk mengamati hewan yang ada di hadapannya. Mereka malah sibuk dengan berbicara hal-hal yang tidak berhubungan dengan materi pembelajaran.

Listening activities siswa masih kurang dalam siklus I. Hal ini dapat dillihat dari hasil penilaian listening activities siswa yang masih mendapatkan nilai K. Dalam kegiatan pembelajaran siswa kurang mendengarkan guru. Seperti pada saat guru menjelaskan cara dan petunjuk pengisian LKS, siswa banyak banyak yang tidak menyimak dengan baik. Akhirnya mereka kurang mampu melaksanakan langkah diskusi berdasarkan petunjuk pada LKS. Pada saat share siswa juga belum mampu menjadi pendengar yang baik bagi temannnya yang sedang melakukan kegiatan share. Mereka seperti acuh saja, seolah-olah teman yang sedang berbicara sendirian.

Oral activities siswa masih sangat minim pada siklus I ini. Berdasarkan hasil pengamatan pada pertemuan pertama dan kedua siklus I, dapat diketahui bahwa siswa kurang mampu untuk mengemukakan pendapatnya saat berlangsungnya diskusi. Siswa terlihat kurang berani dalam berkomentar, mereka kebanyakan diam dan hanya bertindak sebagai pendengar. Siswa juga kurang bersemangat untuk menjawab pertanyaan yang diajukan oleh guru, padahal guru telah berusaha untuk memotivasi dan meyakinkan siswa untuk menjawabnya. Hanya satu oarng siswa saja yang mau berani untuk menjawab pertanyaan yang diajukan oleh guru. Siswa ini merupakan siswa 
yang memiliki kemampuan lebih dibandingkan teman-tenman lainnya. Peneliti tidak lupa unutk memberikan penghargaan bagi siswa yang aktif selama proses pembelajaran berlangsung. penghargaan yang diberikan berupa penghargaan verbal dan non verbal. Hal ini bertujuan untuk memancing dan membangkitkan semangat siswa lainnya untuk ikut terlibat aktif pula.

Writing activities siswa dalam belajar pada siklus I masih kelehatan masih lemah. Siswa belum begitu mampu untuk menuliskan apa yang tealah mereka amati dalam proses diskusi. Siswa sepertinya belum terbiasa untuk membuat laporan hasil pengamatan dalam belajar. Dalam menjawab pertanyaan yang ada terdapat pada LKS, siswa masih kurang mampu untuk dapat menuliskan jawaban dengan benar. hal ini mungkin disebabkan oleh pemahaman siswa yang masih rendah dalam memhami materi pelajaran yang telah didiskusikannya.

Emotional activities siswa masih sangat rendah. Siswa kelihatan kurang semangat dalam belajar. Siswa kebanyakan diam dalam belajar. mereka kelihatan seperti kurang berminat dalam mengutakatik media pembelajaran. Mereka kurang bersemngat dalam berdikusi dan juga kurang mampu mengeluarkan ide-idenya dalam belajar. Padahal peneliti telah berusaha menampilkan media pembelajaran yang bervariasi dalam belajar seperti gambar audio visual dan hewan asli dalam kegiatan belajar. Hal ini disebabkan oleh sikap siswa yang masih canggung dalam belajar dengan menggunakan model kooperatif TPS.

Peneliti juga melakukan penilaian untuk mengukur tingkat kemampuan yang telah dicapai siswa disetiap akhir pembelajaran. Hal ini juga dijelaskan oleh Rusman (2011:54) "bahwa hasil belajar merupakan perubahan perilaku yang terjadi setelah mengikuti proses belajar mengajar sesuai dengan tujuan pendidikan". Berdasarkan pendapat tersebut seorang guru harus merancang suatu evaluasi pembelajaran, untuk mengukur tingkat penguasaan materi dan perubahan perilaku yang terjadi pada siswa. Dalam penelitian ini peneliti mengukur hasil belajar siswa dalam 3 aspek yaitu kognitif (pengetahuan, afektif (sikap) dan psikomotor (keterampilan). Kemampuan kognitif siswa diukur dengan soal-soal tes yang telah peneliti rancang. Kemampuan afektif siswa diukur dengan format observasi afektif yang telah dirancang dengan aspek yang diamati yaitu partisipasi, perhatian dan kerjasama. Ketiga aspek tersebut peneliti menetapkan empat deskriptor yang harus dicapai oleh siswa. Kemampuan psikomotor siswa juga diukur format observasi dengan aspek yang diamati yaitu ketepatan langkah diskusi, ketelitian dalam diskusi dan keruntutan langkah diskusi.

Berdasarkan nilai hasil belajar yang diperoleh oleh siswa pada siklus 
I, maka proses pembelajaran IPA dengan menggunakan model kooperatif tipe TPS belum mencapai target yang diharapkan. Masih banyak siswa yang mendapatkan nilai dibawah ketuntasan belajar yaitu 7,5. Dari aspek kognitif nilai rata-rata kelas hanya mencapai 70 . Dari aspek afektif rata-rata nilai siswa pada siklus I 50,5 masuk dalam kriteria kurang. Sedangkan hasil pembelajaran dari aspek psikomotor pada siklus I mendapatkan nilai 58,6 masuk dalam kriteria kurang.

Rendahnya hasil belajar siswa pada siklus I ini lebih disebabkan oleh tindakan yang dilaksnakan guru pada tahap pelaksnaan masih belum optimal. Guru kurang memotivasi siswa diawal pembelajaran, kurang memotivasi siswa dalam berdiskusi, kurang mampu membantu setiap kesulitan yang dihadapi oleh siswa dalam kelompoknya. Sehingga siswa lebih banyak bersifat pasif dalam kegiatan pembelajaran. Siswa kurang mampu melaksanakan pembelajaran sesuai dengan langkah-langkah pembelajaran model kooperatif TPS. Oleh karena itu peneliti melanjutkan penelitian ke siklus II untuk mencapai tujuan yang diharapkan, yaitu meningkatkan aktivitas dan hasil belajar siswa kelas VI SDN 15 Pakasai kota pariaman.

\section{Penelitian Siklus II}

Pelaksanaan pembelajaran pada siklus II tetap menggunakan langkah-langkah pembelajaran model kooperatif tipe TPS, dimana siswa berfikir, berpasangan dan berbagi. Semua tahapan tersebut telah dapat dilakukan oleh siswa dengan baik. Hal ini sesuai dengan pendapat Taufik (20111:149) yang menjelaskan bahwa "langkah-langkah pembelajaran model kooperatif TPS yaitu: (1) Think (berpikir), (2) Pair (berpasangan), dan (3) Share (berbagi)".

Pada saat kegiatan awal pembelajaran guru menyampaikan tujuan pembelajaran pada siswa. Pada siklus II ini, guru telah mampu menyampaikan tujuan pembelajaran dengan baik. Kalimat yang digunakan guru telah mudah dipahami oleh siswa, sehingga siswa telah mengerti tentang tujuan pelajaran yang akan mereka pelajari. Siswa juga telah mampu untuk menanggapi guru disaat kegiatan apersepsi berlangsung. Sudah ada komentar siswa terhadap pertanyaan yang diberikan oleh guru, dimana siswa sudah bisa menjawab pertanyaan guru. Siswa juga telah mampu menanggapi media pembelajaran yang ditampilkan oleh guru. Siswa bertanya tentang hal-hal yang berhubungan dengan alat peraga yang ditampilkan, guru menjelaskan dengan jelas dan tepat. Hal ini menunjukan bahwa siswa telah mengkonstruksi pengetahuannya secara sendiri dengan bantuan alat peraga. Skemata siswa telah dapat dikembangkannya dengan baik melalaui media nyata yang ditampilkan oleh guru. Artinya sudah ada interaksi yang baik antara guru 
dengan siswa ataupun antara siswa dengan temannya diawal pembelajaran. Kemudian guru telah berusaha dengan maksimal untuk memberikan motivasi pada siswa dalam pembelajaran.

Pada kegiatan inti pembelajaran siswa melakukan diskusi untuk mengidentifikasi ciri khusus pada burung dan kelalawar pada pertemuan pertama dan ciri khusus pada semut hitam dan semut api pada pertemuan kedua. Kegiatan diskusi atau pair pada siklus II sudah berjalan dengan kondusif. Setiap anggota kelompok sudah aktif berpartisipasi dalam kelompoknya masing-masing. Sudah mulai terlihat semangat yang tinggi yang dimunculkan oleh siswa dalam belajar. Siswa telah fokus dan serius dalam mengidentifikasi ciri khusus dari hewan yang sedang didiskusikanya. Guru juga telah mampu membantu kesulitan siswa dalam berdiskusi, semua kelompok mendapatkan perhatian yang sama. Kemudian siswa telah mampu membuat laporan hasil diskusinya dengan baik dan juga telah berani melaporkan hasil diskusi kelompoknya ke depan kelas dengan penuh rasa percaya diri. Siswa dari kelompok lain jug aikut aktif untuk mengomentari hasil laporan kelompok lain, sehingga terjadi suasana tanya jawab yang hidup pada kegiatan ini.

Pada kegiatan share siswa telah mampu untuk saling share dengan temannya dengan baik. Siswa sudah bisa menjelaskan konsep dari materi pelajaran yang telah mereka diskusikan. Siswa yang bertindak sebagai pendengar juga telah mau mendengar dengan penuh perhatian. Kegiatan share ini dipandu oleh guru dengan baik, guru menjelaskan cara melakukan share dengan lebih jelas kepada siswa. Agar siswa lebih terarah dan mengerti dalam share.

Pada siklus II ini aktivitas siswa yang peneliti amati masih sama dengan aktivitas yang diamati dengan siklus I. Aktivitas tersebut adalah: (1) Visual activities, (2) Listening activities, (3) Oral activities, (4) Writing activities, dan (5) Emotional activities. Kelima aktivitas yang akan diamati diukur dengan terlebih dahulu menetapkan deskriptor-deskriptor yang harus dilakukan oleh siswa, dimana untuk setiap aktivitas dibuat empat deskriptor.

Visual activities siswa pada pada siklus II sudah meningkat dibandingkan dnegan siklus I. Hal ini dapat terlihat dari sikap siswa yang sudah serius menyimak seluruh kegiatan pembelajaran secacara penuh. Pada saat penyampaian tujuan pembelajaran siswa telah memperhatikan guru dengan baik. Pada saat diskusi kelompok untuk mengidentifikasi cirri khusus makhluk hidup siswa kelihatan sangat focus untuk mengamati hewan yang ada di hadapannya.

Listening activities siswa telah meningkat pada siklus II. Hal ini dapat dillihat dari hasil penilaian listening activities siswa yang telah 
mampu mendapatkan nilai SB. Dalam kegiatan pembelajaran siswa telah mampu untuk mendengarkan guru dengan sangat baik. Seperti pada saat guru menjelaskan cara dan petunjuk pengisian LKS siswa menyimak dengan baik, sehingga mereka telah mampu melaksanakan langkah diskusi berdasarkan petunjuk pada LKS dengan tepat. Pada saat share siswa sudah mampu menjadi pendengar yang baik bagi temannnya yang sedang melakukan kegiatan share.

Oral activities siswa mengalami peningkatan pad siklus II. Berdasarkan hasil pengamatan pada pertemuan pertama dan kedua siklus II, dapat diketahui bahawa siswa telah mampu untuk mengemukakan pendapatnya saat berlangsungnya diskusi. Siswa telah berani dalam berkomentar, mereka juga telah aktif berkomunikasi secara positif dalam kelompok masing-masing. Siswa juga sudah bersemangat untuk menjawab pertanyaan yang diajukan oleh guru. Hal ini terjadi karena kemampuan guru yang sudah bias memotivasi siswa dengan baik, sehingga sisa mau aktif dalam belajar.

Writing activities siswa dalam belajar pada siklus II mejelaskan bahwa, siswa sudah mampu untuk menuliskan apa yang tealah mereka amati dalam proses diskusi. Siswa sudah bisa membuat laporan hasil pengamatan dalam belajar, dan mampu menjawab pertanyaan yang ada terdapat pada LKS. Hal ini mungkin disebabkan oleh pemahaman siswa yang telah bagus dalam memhami materi pelajaran yang telah didiskusikannya.

Emotional activities siswa sudah mengalami peningkatan yang signifikan. Siswa kelihatan sangat semangat dalam belajar. Siswa telah berbuat aktif dengan berbagai aktivitasnya dalam belajar. mereka kelihatan sudah terlibat terhadap media pembelajaran. Mereka sudah bersemangat dalam berdikusi dan juga telah mampu mengeluarkan ideidenya dalam diskusi. Mulai dari tahap think, pair sampai share siswa telah terlibat aktif dalam pembelajaran.

Hasil belajar siswa dalam pembelajaran IPA dengan menggunakan model kooperatif TPS pada siklus II sudah mencapai target yang diharapkan. Sebagian besar siswa sudah mendapatkan nilai diatas ketuntasan belajar yaitu 7,5. Dari 6 orang siswa hanya 1 orang yang belum mencapai ketuntasan dalam belajar, sedangkan 6 orang lainnya telah mencapaiketuntasan dalam belajar. Dari aspek kognitif nilai ratarata kelas hanya mencapai 88 , nilai ini telah masuk dalam kriteria baik. Dari aspek afektif rata-rata nilai siswa pada siklus II adalah 80,2 masuk dalam kriteria baik. Hasil pembelajaran dari aspek psikomotor pada siklus II ini adalah 92,3 masuk dalam kriteria sangat baik.

Peningkatan hasil belajar siswa pada siklus II ini disebabkan oleh tindakan yang dilaksanakan guru pada tahap pelaksanaan sudah 
optimal, mulaii dari tahap awal sampai akhir pembelajaran. Guru sudah mampu memotivasi siswa dengan menyeluruh, memotivasi siswa dalam berdiskusi, membantu setiap kesulitan yang dihadapi oleh siswa dalam kelompoknya. Siswa juga telah aktif dalam pembelajaran dengan berbagai aktivitas yang dilakukannya. Kemudian siswa telah mampu melaksanakan pembelajaran sesuai dengan langkah-langkah pembelajaran model kooperatif tipe TPS, mulai dari tahap thing, pair dan share secara optimal. Oleh karena itu penelitian pada siklus II ini menunjukan bahwa pelaksanaan pembelajran IPA dengan menggunakan model kooperatif tipe TPS telah berhasil karena dapat meningkatkan aktivitas dan hasil belajar siswa kelas VI SDN 15 Pakasai kota Pariaman.

\section{KESIMPULAN}

Berdasarkan hasil penelitian dan pembahasan, peneliti dapat menarik kesimpulan bahwa: Pembelajaran IPA dengan menggunakan model kooperatif tipe TPS di kelas VI SDN 15 Pakasai kota Pariaman, telah berhasil meningkatkan aktivias siswa dalam belajar. Hal ini dapat dilihat dari nilai yang diperoleh oleh siswa berdasarkan pengamatan yang dilakukan selama proses pembelajaran dilaksanakan. Ada 5 aktivitas yang diamati dalam penlitian ini. Aktivitas tersebut diukur dengan menetapkan deskriptor untuk setiap aktivitas yang diamati, Kelima aktivitas tersebut diamati secara terperinci selama kegiatan penelitian oleh observer. Kemudian pembelajaran IPA dengan menggunakan model kooperatif tipe TPS telah berhasil meningkatkan hasil belajar siswa kela VI SDN 15 Pakasai. Hasil belajar siswa mengalami peningkatan dari asepk kognitif, afektif dan psikomotor.

Berdasarkan hasil dan temuan peneliti selama melakukan penelitian dengan menggunakan model kooperatif tipe TPS di kelas VI SDN 15 Pakasai kota Pariaman, maka peneliti dapat mengemukakan saran sebagai berikut: Untuk mengaktifkan siswa dalam belajar guru sebaiknya melibatkan siswa dalam dengan berbagai aktivitas dalam pembelajaran. Peningkatan aktivitas siswa dalam belajar dapat diukur dengan menggunakan format obsevasi. Pengukuran tersebut dapat dilakukan dengan menetapkan deskriptor dari masing-masing aktivitas yang akan ditingkatkan.

Guru hendaknya mengadakan evaluasi pembelajaran dengan secara objektif dan menyeluruh terhadap masing-masing siswa. Penilaian dapat dilakukan selama proses pembelajaran berlangsung dan diakhir pembelajaran. Guru dapat melakukan penilian terhadap hasil belajar siswa dengan menilai kemampuan siswa dari aspek kognitif, afektif dan psikomotor. Untuk penilaian aspek kognitif dapat dilakukan dengan memberikan soal- 
soal latihan pada siswa. Sedangkan untuk penilaian dari aspek afektif dan psikomotor dapat dilakukan dengan melakukan pengamatan atau obsevasi terhadap siswa.

\section{DAFTAR RUJUKAN}

Arikunto, Suharsimi. 2007. Penelitian Tindakan Kelas. Jakarta: Bumi Aksara.

Asma, Nur. 2006. Model Pembelajaran Koperatif. Jakarta: Depdiknas.

Depdiknas. 2006. Kurikulum Tingkat Satuan Pendidikan. Jakarta: BNSP.

Dwiyanto, Djoko. 2008. Metode Kualitatif Penerapannya Dalam Penelitian. Yogyakarta: Universitas Gadjah mada.

Hamalik, Oemar. 2008. Proses Belajar Mengajar. Jakarta: Bumi Aksara.

Hatmoko, Wiji. 2005. Model Pembelajaran Think Pair and Share (TPS). http://www.google.com. Diakses pada tanggal 7 Juni 2012.

Purwanto. 2011. Evaluasi Hasil Belajar. Yogyakarta: Pustaka Belajar.

Rusman. 2010. Model-model Pembelajaran. Jakarta: PT Raja Grafisindo Persada.

Sanjaya, Wina. 2008. Strategi Pembelajaran Berorientasi Standar Proses Pendidikan. Jakarta: Kencana Prenada Media Group.

Sardiman. 2007. Interaksi dan Motivasi belajar Mengajar. Jakarta: PT Raja Grafisindo.

Slavin, E. Robert. 2009. Cooperative Learning. Bandung: Nusa Media.

Trianto. 2011. Mendesain Model Pembelajaran Inovatif Progresif. Jakarta: Kencana Media Group. 